\section{A justifiable case for support?}

The passing of the old year next week will be celebrated with no little fervour by the UK computer industry. The economic recession triggered by the oil crisis really hit hard during 1975, so much so that survival rather than growth became the priority, and the short-term objectives of maintaining profitability and, even more important, good cash-flow, tended to override all other considerations. Nicholas Enticknap reviews the state of the industry.

$\mathrm{M}$ OST British computer companies can look back on the year with satisfaction. The most important of them, International Computers Ltd (ICL), has just reported its trading figures for the financial year ending September 30 , and these show a $20 \%$ increase in turnover, less than half of which is accounted for by price rises, and a $36 \%$ increase in profit after tax. Another leading company, Data Recording Instrument Co., continued to increase its exports and was able to set up a new subsidiary in France. Two of Britain's largest computer service companies. CMG Computer Management Group and Logica, both increased their turnover by more than $50 \%$ though pre-tax profits were less than hoped for.

On the debit side, Core-Computer Related Equipment, a distributor of imported computer equipment, went into liquidation last month. And a little earlier, Process Peripherals, a company which specialises in specially strengthened data storage devices, ran out of money, in spite of a large and healthy order book. The company's assets have, however, been bought by a British electronic company, GreshamLion, and this has enabled Process Peripherals to carry on.

Looking at the UK industry in a broader context, though, it is still nowhere near to supplying the needs of the country's users, far less becoming a net exporter. 'The most recent year's figures supplied by the Department of Industry are for 1974; they show exports of $£ 210$ million and imports of $£ 346$ million, a net deficit of $£ 136$ million. Total sales of the industry were $£ 517$ million. The figures for the first six months of 1975 are similarly depressing.

But these figures, bad as they are, actually flatter British industry, for they include sales of equipment manufactured in Britain by foreign manufacturers. Four of the top five American computer companies, IBM, Honeywell, Burroughs, and NCR, have factories in the UJK, most of them located in Scotland. These factories do. of course, contribute to the balance of payments and provide employment, but the profits end up in American rather than British pockets.

Market shares provide another measure of the success of British industry, though admittedly a controversial one as the arguments over the definition of the market and the best method of valuation are endless. According to ICL executives, who can reasonably be expected to be as favourable to ICL as anybody, their company is maintaining a steady $38 \%$ share of the total value of all computers installed in the UK. No other British company has a significant share, so well over half the computer equipment in use in Britain was made by foreign companies.

This again, unsatisfactory though it is, is flattering rather than the reverse, because, for example, many of ICL's computers use disk drives designed and manufactured in America, and these can account for a substantial proportion of a computer system's total value. Nonetheless ICL, which was formed by merger of several different computer companies in 1968 , has done well; it has a larger share of its home market than any major computer company, other than IBM, albeit in somewhat artificial market conditions. IBM is the giant of the industry, and has sold between 60 and $70 \%$ of the total value of all computers installed worldwide-only in Britain and Japan of the industrialised countries does it have less than $50 \%$.

ICL sells 'mainframe' computers, which are general purpose systems ranging in value from around $£ 30,000$ computer, the minicomputer, is normally used for one or two specific tasks such as control of an industrial process, but is increasingly being adopted for commercial use. Prices range from around $£ 1,000$ up to around $£ 100,000$, but nonetheless, minicomputer business is big business-the leading manufacturer, Digital Equipment Corp., has a turnover of $\$ 500$ million.

Britain's record in this area is little short of appalling. There has been no attempt to merge the number of small companies competing with each other into one cohesive unit, with the result that none of them has become a major force, and most of them have suffered financial disaster. Ferranti, whose to several millions. Another class of troubles are well known, is the biggest producer, with a manufacturing volume of around 30 systems a month. This compares with over 100 produced by the Swedish company Datasaab, and volumes ranging from 350 to 500 for the leading American manufacturers.

This record is not due to poor design, for British minicomputers have generally received high marks for technological expertise and innovation in independent surveys. It is primarily due to the limited size of the home market, which simply cannot support a large number of companies. This means that development costs are spread over a smaller number of units, so prices are higher and contracts are lost. Furthermore, there is no preferential purchasing policy by government departments to compare with that enjoyed by ICL.

The question of government involvement in the computer industry is a perennial source of concern. There can be no doubt that the government should formulate a policy. The net deficit in the balance of payments should in itself be a matter of national concern, the more so as sales of computer equipment are projected to grow by $15 \%$ a year in the UK into the indefinite future. The types of computer equipment that have the biggest growth potential-minicomputers, terminals and microcomputers-are all dominated by American companies to an even greater extent than the mainframe business, so the trading imbalance is likely to get much worse unless corrective action is taken.

In spite of this, the government has never had a planned policy for the computer industry, and has merely responded to individual problems when sufficient pressure has been exerted. This is extraordinary considering the enormous sums of money spent on the motor industry this year in the face of advice from government bodies that there is little prospect of a return on this investment. The bills for Concorde have come to around $£ 1,500$ million, spent in the cause of developing new technology. Yet the computer industry both embodies new technology and offers hope for a return on investment, but has only received government funds to the tune of around $£ 50$ million since the formation of ICL.

This $£ 50$ million is largely accounted for by an investment-free loan of $£ 40$ million to ICL for development of its latest range of computers, the 2900 series. Other smaller sums have been made available to a number of companies through the National Research Development Corporation and the National Computing Centre, but these have all funded a maximum of half the total cost of each development project. The government does help in one 
other way, by requiring its own departments to buy British (which means ICL) when purchasing any computer with more than a specified amount of computer power.

One result of this lack of support is to induce British companies to adopt an "if you can't beat them, join them" policy. ICL has joined in a three-sided agreement with two American companies, NCR and Control Data Corporation, covering the development and manufacturer of peripherals. Data
Recording Instrument Company has similarly made agreements with various North American companies concerning the supply and manufacture of disk drives.

It is depressing to move into 1976 without any sign of a change of attitude from the British government. Certainly none could be detected in the speech made by Eric Varley, Secretary of State for Industry, at the opening this month of the National Computing Centre's new headquarters. Still, it could be worse. One of the saddest events of 1975 was the collapse of Unidata, a pan-European computer manufacturer formed from the French government company Compagnie Internationale pour l'Informatique, and from the computer subsidiaries of Philips of Holland and Siemens of Germany. ICL was at one stage under considerable pressure to join this triumvirate, but resisted, and consequently remains alive and well-and profitable.
When the Loch Ness Monster ostensibly raised its ugly head (see picture) jects was made to identify the obwith the support of Sir Peter Scott, for qualified biologists to do-not him widespread public interest was in- self. evitable. What was far less certain was the reaction of the scientific community. As it turns out, Scott and his colleague Robert Rines must be reasonably content.

Their original plan was to present at a two-day scientific symposium the full evidence which they felt supported the existence of large animals in Loch Ness. The outcome, they hoped, would at least allow the existence of the animal to be given the benefit of the doubt. They also wanted it officially named in order to have it legally protected as an endangered species. An attack of cold feet gripped the organisers of the symposium, however, and they withdrew their support.

The only forum left for the presentation of evidence was a meeting in the Grand Committee room at the House of Commons-a room, some would say, that is steeped in the history of monstrous debate. It was held on the evening of December 11 before representatives of the public, the press, and the scientific community, along with Members of Parliament understandably seeking relief from the second reading of the Armed Forces Bill, which was making $\mathrm{Mr}$ Wellbeloved less endearing then Nessie.

The bulk of the meeting was devoted to presentations by members and associates of the Academy of Applied Science-a 'non-profit, scientific and educational corporation' lodged at the Boston home of its president, Robert Rines. The academy has been investigating Loch Ness every summer for the past five years.

The optical and sonar systems used and the site chosen for the attempt to obtain underwater photographs of the monster were both presented in dazzling detail. Much was then made of the 1972 photographs which, after computer enhancement, showed 'flipper-like objects'. But when it came to the expected climax of the 1975 photographs, Rines' presentation was so modest that he nearly blushed. No

Three biologists handily placed on the platform then stated their beliefs that the photographs contained various images suggestive of flippers, a body

\section{Nessiteras skeptyx}

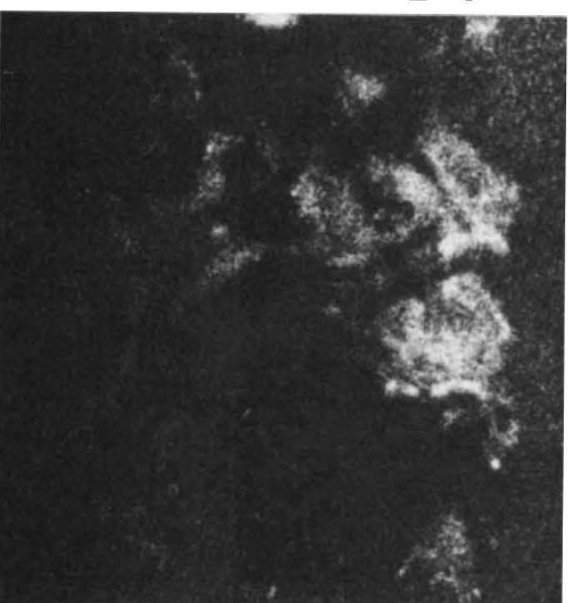

and a head, all of which indicated the presence of large animals in Loch Ness. In that they were further supported by a statement from Professor A. W. Crompton of Harvard. None of the biologists, however, was prepared to try to identify the animal.

The discussion period that closed the meeting provided few fireworks. Most of the questions were on a scientist-toscientist basis; they ranged from the problem of whether the animal would be air-breathing to queries about size controls for the objects photographed. Critical comments attained various levels. Hugh Fraser MP said that judging by his disappointing fishing experience in Loch Ness, the salmon population of 13 million claimed earlier in the evening was a gross exaggeration. He did not profer an alternative explanation of his performance, relating to the likely appetites of any animals in the Loch. David Attenborough suggested that the 1972 flipper-like obiects might actually be the fin of a fish. And that, it seemed, was the cue for the heavy artillery from the British Museum to open fire.

Dr Gordon Sheals supported the view that the flippers were fish fins, and that their estimated size was "wildly" miscalculated. When that was disputed and further claims were made for the presence of a large animal, he decided it was time to broaden the attack. There was, he said, no evidence to support the view that the same object was shown in each photograph, nor to suggest that any of them showed a living object. Furthermoreand this was the body blow-it was most regrettable that Nature had published the article by Scott and Rines.

Another sceptic from the British Museum, Dr Humphrey Greenwood, conceded what several more sympathetic voices had already suggestedthat there was a sufficient case for the evidence now to be published in full detail so that it could be properly scrutinised. The delighted Dr Rines clearly felt the battle was half won. $\mathrm{He}$ was at least being taken seriously.

Less serious was the response of the mass media. By and large the photographs were presented with a healthy dose of scepticism to accompany them and some astonishing artist's impressions of what they showed. The more enterprising journalists managed to winkle out people with something they thought approached a knowledgeable view. Unsurprisingly, the claims were as diverse as they were knowledgeable. One view was that the photographs actually showed parts of a Viking ship. Another, on television, was that the "head" was of a scuba diver wearing his breathing apparatus back to front. The grateful monster-following public also learned that the British Bacon Curers' Federation was to organise a hunt for Nessie by hot air balloon.

If the eventual truth of the monsterhunters' claims is still breathlessly awaited, at least they, though perhaps not their prey, have finally come in from the cold. That may be the epitaph on this episode. In the next one, the natural history of L.och Ness may even become a respectable line of study. 